\title{
ANALISIS KESALAHAN GURU MATEMATIKA MADRASAH IBTIDAIYAH ACEH BESAR TERHADAP GEOMETRI
}

\author{
Kamarullah \\ Balai Diklat Keagamaan Aceh, Jalan Syiah Kuala 116, Banda Aceh 23123, Indonesia \\ Email: kamarullahpindra@yahoo.co.id
}

\begin{abstract}
Abstrak
Sebagai guru matematika madrasah ibtidaiyah (MI), maka pengetahuan tentang objek geometri MI merupakan pengetahuan wajib untuk dikuasai. Apabila pengetahuan tentang objek tersebut keliru, maka kemungkinan besar apa yang akan diajarkan kepada anak didik juga akan keliru, jika kekeliruan tersebut tidak disadari, akan berlangsung secara terus menerus dalam waktu yang relatif lama. Penelitian bertujuan untuk mendeskripsikan profil penguasaan guru matematika MI Aceh Besar, menganalisis kesalahann guru, menentukan penyebab guru melakukan kesalahan dalam geometri di MI. Penelitian ini berbentuk penelitian deskriptif dengan menggunakan pendekatan kualitatif dan kuantitatif. Tes penguasaan dilakukan terhadap 40 guru; penentuan jenis dan penyebab kesalahan dilakukan melalui wawancara terhadap 3 guru. Berdasarkan analisis data hasil penelitian diperoleh kesimpulan sebagai berikut: Untuk skor kategori penguasaan materi ajar geometri di MI skor rata-rata yaitu 13,75 (38,19\%). Untuk kategori penguasaan objek geometri di MI skor rata-rata 9,49 (27,11\%). Jenis kesalahan meliputi kesalahan konsep, prinsip dan operasi. Penyebab kesalahan, tidak memahami konsep sumbu simetri, segiempat, tidak memahami prinsip pencerminan; Tidak menguasai sifat segiempat; Tidak terbiasa mengungkapkan definisi dari sebuah konsep; Belum memahami cara mendefinisikan sebuah konsep; Belum menguasai konsep bangun ruang, Belum memahami konsep sisi, rusuk, dan titik sudut bangun ruang; Belum menguasai prinsip menghitung luas bangun datar; Salah memahami soal atau kealpaan.
\end{abstract}

Kata Kunci: Geometri, Kesalahan Guru, Jenis kesalahan, Penyebab Kesalahan

\begin{abstract}
As a mathematics teacher at the Madrasah Ibtidaiyah (MI), then knowledge of MI geometry objects is mandatory knowledge to mastered. If the knowledge of the object is wrong, then it is likely that what will be taught to students will also be wrong, if the mistake is not realized, it will take place continuously for a relatively long time. The research aims to describe the mastery profile of mathematics teacher MI Aceh Besar, analyze teacher errors, determine the cause of teachers making errors in geometry in MI. This research is in the form of descriptive research using qualitative and quantitative approaches. The tests were conducted on 40 teachers; Determination of types and causes of errors is done through interviews with 3 teachers. Based on the analysis of data the results of the study obtained the following conclusions: For the score of the mastery category of geometry teaching material in MI the average score was $13.75(38.19 \%)$. For the mastery of geometry objects in MI the average score was 9.49 (27.11\%). Types of errors include conceptual errors, principles and operations. The cause of the error, does not understand the concept of the symmetry axis, rectangles, does not understand the principle of reflection; Not mastering the rectangle properties; Not used to expressing the definition of a concept; Don't understand how to define a concept; Not yet mastering the concept of geometry, Not yet understanding the concept of sides, lateral, and vertex geometrical; Not yet mastered the principle of calculating the area of two-dimensional figure; Misunderstanding the problem or neglect.
\end{abstract}

\section{Keywords: Geometry, teachers' fault, types of mistake, the cause of error}

\section{PENDAHULUAN}

Matematika yang diajarkan diberbagai jenjang pendidikan sekolah disebut dengan matematika sekolah yaitu bagian dari matematika yang dipilih berdasarkan dan berorientasi kepada kepentingan pendidikan serta perkembangan ilmu pengetahuan dan teknologi. Tujuan pendidikan matematika 
tersebut adalah seperti yang dikemukakan oleh Soedjadi (2000: 66) yaitu tujuan yang bersifat formal dan material.Tujuan yang bersifat formal yaitu tujuan yang menekankan pada penataan nalar siswa serta pembentukan pribadinya. Tujuan yang bersifat material adalah tujuan yang menekankan pada penerapan matematika baik dalam matematika sendiri ataupun di luar matematika. Penekanan tujuan pendidikan matematika tersebut di setiap jenjang pendidikan berbeda, bergantung kepada jenis jenjang pendidikan tersebut, sebagai contoh untuk pendidikan kejuruan, maka tujuan yang bersifat material akan lebih besar dari sekolah umum. Secara khusus tujan pendidikan matematika di Madrasah Ibtidaiyah seperti yang tercantum dalam kurikulum matematika tahun 2016 (K13 Revisi) yaitu: Menumbuhkan dan mengembangkan keterampilan berhitung (menggunakan bilangan) sebagai alat dalam kehidupan sehari-hari; Menumbuhkan kemampuan siswa, yang dapat dialih gunakan melalui kegiatan matematika; Mengembangkan pengetahuan dasar matematika sebagai bekal belajar lebih lanjut di Madrasah Tsanawiyah (MTs); Membentuk sikap logis, kritis, cermat, kreatif dan disiplin.

Berdasarkan tujuan pendidikan matematika Madrasah Ibtidaiyah di atas, maka jelas bahwa matematika Madrasah Ibtidaiyah merupakan landasan pertama untuk belajar matematika ketingkat selanjutnya yaitu: Tsanawiyah/SLTP, Aliyah/SMU/SMK maupun perguruan tinggi, hal ini sesuai dengan yang di kemukakan oleh Skemp (1982: 36) yaitu tahap awal belajar matematika berlangsung di sekolah dasar.

Geometri merupakan bagian dari matematika yang sudah mulai diajarkan semenjak di Madrasah Ibtidaiyah yang memiliki tujuan yang sama dengan tujuan pendidikan matematika secara umum seperti yang telah disebutkan di atas. Kennedy dan Tipps (1994: 385) menyatakan bahwa melalui pengalaman belajar geometri dapat meningkatkan ketrampilan pemecahan masalah, penalaran, dan mendukung untuk mempelajari berbagai topik matematika. Serta mendukung untuk mempelajari berbagai ilmu pengetahuan yang lain, (Clements dan Battista, 1992: 475).

Berdasarkan kutipan di atas, jelas bahwa belajar geometri tidak hanya berhubungan dengan matematika semata, akan tetapi melalui pembelajaran geometri juga mendukung untuk mempelajari berbagai cabang ilmu pengetahuan lain. Melalui pembelajaran geometri juga dapat meningkatkan minat anak terhadap matematika, karena geometri sebagai bagian dari matematika, didalamnya banyak membahas bentuk-bentuk bangun seperti persegi, kubus, prisma dan lain-lain yang telah dikenal dan diakrabi siswa sejak masa kanak-kanak. Baik itu dari mainan anak sendiri, maupun melalui objek-objek visual disekitar mereka. Dengan demikian secara alamiah, geometri akan menarik bagi siswa Madrasah. Karena itu, geometri di Madrasah Ibtidaiyah merupakan materi yang strategis untuk mendorong peningkatan kualitas proses dan hasil belajar matematika.

Kenyataan menunjukkan bahwa hasil belajar matematika khususnya geometri di Sekolah Dasar/Madrasah Ibtidaiyah masih belum memuaskan. Salah satu bukti masih rendahnya prestasi belajar matematika di Madrsah Ibtidaiyah yaitu nilai rata-rata ujian akhir sekolah berstandar nasional mata pelajaran matematika untuk tingkat MI di lingkungan Kementerian Agama Aceh Besar tahun 
2018 adalah 58,2 (Arsip Rekapitulasi hasil UAMBN MI Kemenag Aceh Besar). Selain itu berdasarkan hasil analisis hasil jawaban siswa, soal aspek geometri merupakan soal yang berkategori sukar bagi siswa.

Kurangnnya penguasaan siswa terhadap konsep dan prinsip dalam geometri, tentunya disebabkan oleh berbagai faktor, salah satunya yaitu faktor guru. Hudoyo (1988:7), mengemukakan bahwa penguasaan materi dan cara penyampaian materi merupakan syarat yang tidak dapat ditawartawarkan lagi dalam matematika. Dari kutipan ini jelas bahwa kelemahan yang mungkin terjadi pada diri seorang guru dapat berupa penguasaan materi, maupun penggunaan metode, namun diantara kelemahan tersebut yang sering diamati yaitu kesalahan dari segi cara mengajar (metode) sedangkan kelemahan yang berupa kekeliruan konsep sulit untuk diamati, hal ini sesuai dengan yang dikemukakan oleh Soedjadi (1992 : 31): Kekeliruan/kelemahan guru seringkali tidak diketahui dan tidak dapat dibetulkan karena tidak ada seorangpun yang mengetahui terjadi kekeliruan itu. Sering kali yang diamati/diawasi hanya cara mengajar tanpa mengerti adanya kekeliruan konsep yang diajarkan. Kekeliruan yang demikian dapat terjadi berlarut-larut hingga tahunan. Rendahnya kemampuan yang dimiliki oleh guru, terutama kemampuan dalam penguasaan materi merupakan akibat dari kemampuan yang didapat ketika masih dalam masa pendidikan terutama pendidikan keguruan masih sangat rendah.

Berdasarkan latar belakang tersebut di atas, maka penulis tertarik untuk mengetahui penguasaan guru matematika MI tentang geometri di Madrasah Ibtidaiyah, menganalisis kesalahan yang diperbuat guru matematika.

Pertanyaan dalam penelitian ini yaitu: Bagaimana profil penguasaan geometri di Madrasah Ibtidaiyah guru matematika MI Aceh Besar?; Jenis kesalahan apa yang dilakukan oleh guru matematika MI dalam menyelesaikan soal tes penguasaan materi geometri di Madrasah Ibtidaiyah? Faktor-faktor apa saja yang menyebabkan guru matematika MI mengalami kesalahan dalam menyelesaikan soal-soal tes geometri di Madrasah Ibtidaiyah?

Sesuai dengan pertanyaan penelitian, maka yang menjadi tujuan dari penelitian ini yaitu: Untuk mendeskripsikan profil penguasaan guru matematika MI terhadap materi geometri di Madrasah Ibtidaiyah; Untuk menganalisis kesalahan-kesalahan guru guru matematika MI dalam geometri di Madrasah Ibtidaiyah; Untuk menentukan penyebab terjadinya kesalahan guru guru matematika MI dalam geometri di Madrasah Ibtidaiyah.Agar tidak terjadi kekeliruan penafsiran, berikut akan diberikan beberapa batasan istilah:

Geometri di Madrasah Ibtidaiyah dalam penelitian ini yaitu geometri yang terdapat dalam kurikulum Madrasah Ibtidaiyah tahun 2016 (K13 Revisi). Selanjutnya objek-objek geometri tersebut penulis bagi dua bagian yaitu: Pertama Objek-objek geometri yang dipelajari siswa Madrasah Ibtidaiyah yang terdapat dalam kurikulum dan buku resmi yang dikeluarkan pemerintah, selanjutnya dinamakan materi ajar geometri di Madrasah Ibtidaiyah. Kedua objek geometri yang tidak diajarkan di Madrasah Ibtidaiyah, tetapi harus dikuasai oleh guru-guru Madrasah Ibtidaiyah agar dapat 
memahami materi geometri di Madrasah Ibtidaiyah, contoh definisi trapesium. Selanjutnya bagian ini disebut objek geometri.

Yang dimaksud dengan analisis adalah suatu upaya untuk melihat, mengetahui, menemukan, memahami, menelaah, mengklasifikasi, mendalami dan mengiterpretasi fenomena yang menjadi sasaran penelitian. Dalam penelitian ini sasaran perhatian adalah kemampuan guru matematika MI di Aceh Besar terhadap materi geometri di Madrasah Ibtidaiyah.

Profil yang dimaksud pada penelitian ini adalah: kondisi (keadaan atau gambaran) tentang banyak dan persentase guru matematika yang berada pada tingkatan klasifikasi penguasaan tertentu dalam penguasaan materi dan objek geometri di Madrasah Ibtidaiyah (yang ditandai dengan skor tertentu).

Penguasaan yang dimaksud dalam penelitian ini yaitu: kemampuan guru matematika dalam menguasai geometri di Madrasah Ibtidaiyah. Untuk mengetahui kemampuan guru matematika dalam menguasai geometri di Madrasah Ibtidaiyah, peneliti meninjau dari skor yang diperoleh guru matematika dalam mengerjakan soal tes.

Kesalahan adalah: penyimpangan dari yang benar (yang telah disepakati). Jenis kesalahan adalah: klasifikasi kesalahan yang dapat diperbuat oleh guru matematika dalam menjawab soal tes yang berupa kesalahan konsep, prinsip atau operasi. Penyebab kesalahan adalah segala hal yang menyebabkan terjadinya kesalahan. Penyebab kesalahan yang ditinjau khusus yang berasal dari dalam diri guru matematika khususnya aspek kognitif yang berkaitan dengan objek geometri.

Hasil penelitian ini diharapkan dapat bermanfaat: Sebagai sumbangsih untuk perkembangan ilmu pengetahuan, utamanya menyangkut dengan materi geometri di Madrasah Ibtidaiyah; Sebagai bahan renungan bagi guru matematika MI agar lebih meningkatkan kemampuannya terhadap matematika terutama geometri dan dapat memperbaiki kesalahan-kesalahan konsep yang telah dikuasai; Sebagai bahan pertimbangan bagi pengambil kebijakan pelaksanaan diklat khususnya di BDK Aceh dan Indonesia umumnya; Sebagai salah satu pedoman bagi Widyaiswara pengajar diklat teknis subtantif matematika MI di BDK Aceh.

\section{METODE PENELITIAN}

\section{Jenis Penelitian}

Dalam penelitian ini digunakan pendekatan kuantitatif dan kualitatif. Pendekatan kuantitatif digunakan untuk mendiskriptifkan profil penguasaan guru matematika MI terhadap geometri di Madrasah Ibtidaiyah dengan cara memberikan seperangkat tes tertulis yang berisi sejumlah soal sesuai dengan kriteria penguasan.

Pendekatan kualitatif digunakan untuk menentukan jenis kesalahan dengan cara menganalisis jawaban tes guru. Sedangkan untuk mengetahui penyebab melakukan kesalahan, dilakukan melalui teknik wawancara. 


\section{Subjek Penelitian}

Subjek penelitian ini adalah seluruh guru matematika MI se Kabupaten Aceh Besar tahun 2018 yang berjumlah 63 orang dan tersebar pada 53 MI Negeri dan swasta. Namun karena keterbatasan peneliti, terutama keterbatasan waktu, tidak seluruh guru akan diberikan tes kemampuan geometri. Tes Geometri akan dilakukan terhadap 40 orang guru. Pengambilan sampel dilakukan secara acak yaitu dengan cara mengundi nama guru.

Selanjutnya untuk keperluan kualitatif, terutama untuk menentukan penyebab melakukan kesalahan, dipilih 3 orang guru sebagai subjek untuk diwawancarai. Pemilihan guru yang akan diwawancari dilakukan setelah jawaban tes diperiksa. Yang menjadi pertimbangan dalam menentukan subjek yang akan diwawancarai yaitu antara lain: Banyak melakukan kesalahan dalam menjawab tes; Kesalahan yang dilakukan mewakili keberagaman kesalahan yang muncul; Bersedia untuk diwawancarai.

\section{Jenis dan Sumber Data}

Untuk data kuantitatif diperoleh melalui tes yang diberikan kepada guru yang dipilih sebagai subjek penelitian. Tes yang diberikan berupa soal essay yang berisi soal geometri sesuai dengan kriteria penguasaan yang telah ditetapkan. Data kualitatif untuk menyelidiki kesalahan yang dilakukan guru, diperoleh dengan cara menganalisis jawaban yang diberikan melalui tes. Sedangkan untuk menentukan penyebab melakukan kesalahan, dilakukan wawancara dengan guru yang terpilih untuk diwawancarai seperti yang telah disebutkan sebelumnya.

\section{Teknik dan Instrumen Pegumpulan Data}

Pada penelitian ini digunakan seperangkat instrumen tes penguasaan geometri di Madrasah Ibtidaiyah. Tes yang diberikan berupa tes diagnostik dalam bentuk essay. Materi yang akan di tes dibagi kepada dua bagian yaitu materi ajar geometri dan materi objek geometri. Materi ajar geometri di MI ditinjau yang berkaitan dengan penelitian ini yaitu: bangun-bangun datar, pencerminan dan bangun-bangun ruang. Selanjutnya materi-materi tersebut dikelompokkan dalam 3 kategori penguasaan $(\mathrm{KP})$ yaitu:

Kategori penguasaan satu yaitu: Menentukan sisi segitiga yang dapat dijadikan alas, untuk menghitung luas segitiga dengan menggunakan rumus luas segitiga; Menentukan tinggi segitiga jika alas diketahui; Menyebutkan trapesium diantara bangun-bangun segiempat; Menyebutkan layanglayang diantara bangun-bangun segiempat; dan Menulis rumus keliling bangun segiempat

Kategori penguasaan dua yaitu: melukis bayang suatu bangun bila dicerminkan terhadap suatu garis; menyebutkan syarat-syarat suatu segiempat mempunyai sumbu simetri g (sumbu simetri tertentu); menyebutkan banyaknya sumbu simetri pada jajargenjang; dan menyebutkan banyaknya sumbu simetri pada layang-layang. 
Kategori penguasaan tiga yaitu: menyebutkan bentuk-bentuk bangun ruang; menyebutkan sisi alas bangun prisma bila ingin menghitung volume prisma; menyebutkan sisi, rusuk dan titik sudut suatu bangun ruang; menyebutkan prisma diantara bangun-bangun ruang; dan menyebutkan limas diantara bangun-bangun ruang.

Objek geometri di MI pada penelitian ini adalah sebutan untuk materi yang bukan materi ajar geometri di MI, akan tetapi perlu dikuasai oleh guru matematika MI, sebagai modal untuk dapat memahami materi ajar geometri di MI, sehingga ketika mengajar akan mudah untuk menyampaikan suatu konsep kepada anak didik. Materi objek geometri di MI yang diperhatikan pada penelitian ini adalah pemahaman konsep bangun segiempat dan pendefinisian bangun-bangun segiempat, hal ini perlu dikuasai guru, agar tidak terjadi kesalahan konsep dalam penyampaian terhadap anak didik tidak, dan anak didik akan lebih mudah memahami konsep yang diajarkan. Selanjutnya kategori penguasaan objek geometri ini dikelompokkan pada kategori penguasaan empat.

Kategori penguasaan 4 pada penelitian ini yaitu: menyatakan definisi bangun segitiga, segitiga sama sisi, segitiga tumpul dengan kata-kata sendiri; menyatakan definisi bangun-bangun segiempat (segiempat, jajargenjang, persegipanjang, persegi, belahketupat, layang-layang dan trapesium) dengan kata-kata sendiri.

Tes tersebut disamping untuk mendapatkan data tentang kemampuan guru matematika terhadap geometri di Madrasah Ibtidaiyah, juga bertujuan untuk mendiagnosis letak dan jenis kesalahan yang dilakukan Guru.

Diagnosis jenis kesalahan dan penyebab melakukan kesalahan, juga akan dilakukan melalui wawancara. Wawancara akan dilakukan dengan guru yang telah dipilih sebagai subjek berdasarkan hasil tes yang telah diberikan, pemilihan guru yang akan diwawancara didasarkan atas kriteria yang telah disebutkan di atas.

Dalam melakukan wawancara, peneliti berpandu kepada pedoman umum wawancara yang telah disusun terlebih dahulu. Pedoman umum wawancara disusun berdasarkan pertimbangan dari hasil tes dan sesuai dengan kesalahan yang didapat dari hasil analisis jawaban tes. Pedoman umum wawancara hanya memuat sebagian besar tentang hal-hal yang akan ditanyakan. Sedangkan untuk pertanyaan secara lebih terinci akan peneliti sesuaikan ketika proses wawancara berlangsung.

\section{Analisis Data}

Data yang akan diolah disesuaikan dengan pertanyaan yang akan dijawab.

\section{- Pemeriksaan Jawaban Tes}

Setelah jawaban guru sebagai sampel diperikas, selanjutnya akan dilakukan pengkategorian kemampuan guru sebagai berikut: Seorang guru dikatakan menguasai kategori penguasaan satu, jika seorang guru dapat menjawab dengan benar seluruh soal kategori satu yang diberikan. Jika diukur dengan skor yang diperoleh, sekurang-kurangnya 75\% dari skor maksimal ideal (SMI) pada kategori penguasaan satu (0,75 X SMI 1). Seorang guru dikatakan menguasai kategori penguasaan dua, jika 
seorang guru dapat menjawab dengan benar seluruh soal kategori dua yang diberikan. Jika diukur dengan skor yang diperoleh, sekurang-kurangnya 75\% dari skor maksimal ideal (SMI) pada kategori penguasaan dua (0,75 X SMI 2). Seorang guru dikatakan menguasai kategori penguasaan tiga, jika seorang guru dapat menjawab dengan benar seluruh soal kategori tiga yang diberikan. Jika diukur dengan skor yang diperoleh, sekurang-kurangnya 75\% dari skor maksimal ideal (SMI) pada kategori penguasaan tiga (0,75 X SMI 3). Seorang guru dikatakan menguasai kategori penguasaan empat, jika seorang guru dapat menjawab dengan benar seluruh soal kategori empat yang diberikan. Jika diukur dengan skor yang diperoleh, sekurang-kurangnya 75\% dari skor maksimal ideal (SMI) pada kategori penguasaan empat $(0,75 \mathrm{X}$ SMI 4$)$.

Penentuan klasifikasi penguasaan guru diadaptasi dari klasifikasi yang dikemukakan oleh Suharsimi Arikunto (Arikunto, 1996: 244), maka pada penelitian ini ditetapkan klasifikasi yaitu: Seorang guru dikatakan sangat menguasai suatu kategori penguasaan tertentu yaitu, jika seorang guru dapat menjawab dengan benar seluruh soal kategori satu yang diberikan. Jika diukur dengan skor yang diperoleh, sekurang-kurangnya 76\% dari skor maksimal ideal (SMI) yaitu skor maksimal yang dapat diperoleh guru pada kategori penguasaan tersebut. Seorang guru dikatakan menguasai suatu kategori penguasaan tertentu yaitu, jika skor tes yang diperoleh guru berkisar antara $56 \%-75 \%$ dari skor maksimal ideal untuk kategori yang bersangkutan. Seorang guru dikatakan kurang menguasai suatu kategori penguasaan tertentu yaitu, jika skor tes yang diperoleh guru berkisar antara $40 \%-55 \%$ dari skor maksimal ideal untuk kategori yang bersangkutan. Seorang guru dikatakan tidak menguasai suatu kategori penguasaan tertentu yaitu, jika skor tes yang diperoleh guru 0\% - 40\% dari skor maksimal ideal untuk kategori yang bersangkutan.

Dalam menganalisis jawaban tes, peneliti juga akan membuat rangkuman tentang jenis dan penyebab melakukan kesalahan yang selanjutnya akan dijadikan pertimbangan dalam memilih guru yang akan diwawancarai dan penyusunan pedoman umum wawancara.

\section{- Analisis Hasil Wawancara}

Analisis hasil wawancara bertujuan untuk mendapatkan data tentang penyebab guru melakukan kesalahan. Hasil analisis wawancara juga akan dijadikan sebagai bahan triangulasi data.

Dalam menganalisis hasil wawancara, penulis berpedoman pada langkah-langkah tahapan yang dikemukan oleh Miles (1992; 16): Mereduksi data, kegiatan yang mengacu pada proses menyeleksi, menyederhanakan, mengelompokkan, mengabtraksikan, dan mentranformasikan data mentah yang tertulis dan direkam dalam catatan laporan; Menyajikan data, menulis laporan dan mentranformasikan data mentah sehingga memungkinkan menafsirkan, memberikan makna dan pengertian; Menyimpulkan data, menarik kesimpulan dari data yang telah ditentukan. 


\section{HASIL PENELITIAN DAN PEMBAHASAN}

\section{Deskripsi Data Hasil Tes dan Penguasaan Guru}

Berikut merupakan distribusi skor yang diperoleh guru berdasarkan kategori penguasaan.

Tabel 4.1 Distribusi Skor Tes Guru Berdasarkan Kategori Penguasaan

\begin{tabular}{|c|c|c|c|c|c|c|}
\hline \multirow{2}{*}{$\begin{array}{l}\text { KODE } \\
\text { GURU }\end{array}$} & \multicolumn{4}{|c|}{$\begin{array}{c}\text { SKOR PADA SETIAP KATEGORI } \\
\text { PENGUASAAN }\end{array}$} & \multirow{2}{*}{$\begin{array}{l}\text { SKOR } \\
\text { TOTAL }\end{array}$} & \multirow[t]{2}{*}{$\%$} \\
\hline & KP 1 & KP 2 & KP 3 & KP 4 & & \\
\hline G1 & 3 & 0 & 8,5 & 6,5 & 18 & 25,35 \\
\hline G2 & 3 & 1,75 & 7 & 7 & 18,75 & 26,41 \\
\hline G3 & 5 & 4,5 & 9,25 & 5,5 & 24,25 & 34,15 \\
\hline G4 & 2 & 3 & 8 & 0 & 13 & 18,31 \\
\hline G5 & 2,75 & 4,5 & 7,5 & 7 & 21,75 & 30,63 \\
\hline G6 & 1,5 & 1,5 & 1,75 & 0,5 & 5,25 & 7,39 \\
\hline G7 & 5 & 3,5 & 9,75 & 5,5 & 23,75 & 33,45 \\
\hline G8 & 3,5 & 1,25 & 9,5 & 2,5 & 16,75 & 23,59 \\
\hline G9 & 4,25 & 0,5 & 10,25 & 5 & 20 & 28,17 \\
\hline G10 & 3,25 & 4 & 6 & 14,5 & 28,25 & 39,79 \\
\hline G11 & 3,25 & 3 & 7,25 & 12 & 26,5 & 37,32 \\
\hline G12 & 1,75 & 1,25 & 2,75 & 5 & 10,75 & 15,14 \\
\hline G13 & 3 & 1,5 & 2 & 4,5 & 11 & 15,49 \\
\hline G14 & 3 & 0 & 5 & 10 & 18 & 25,35 \\
\hline G15 & 5 & 3 & 8,5 & 7,5 & 24 & 33,80 \\
\hline G16 & 5,75 & 3,5 & 11,25 & 7 & 27,5 & 38,73 \\
\hline G17 & 5,25 & 3,5 & 10,75 & 8 & 27,5 & 38,73 \\
\hline G18 & 5,25 & 1,5 & 8,75 & 12 & 27,5 & 38,73 \\
\hline G19 & 4 & 3 & 9,75 & 10 & 26,75 & 37,68 \\
\hline G20 & 4,25 & 3 & 4,75 & 10,5 & 22,5 & 31,69 \\
\hline G21 & 3,75 & 2,5 & 7 & 17,5 & 30,75 & 43,31 \\
\hline G22 & 4 & 3,5 & 9 & 3 & 19,5 & 27,46 \\
\hline $\mathrm{G} 23$ & 3,5 & 3,5 & 7 & 15,5 & 29,5 & 41,45 \\
\hline $\mathrm{G} 24$ & 2,5 & 1,5 & 2,5 & 12,5 & 19 & 26,76 \\
\hline G25 & 4 & 3,5 & 9,5 & 15,5 & 32,5 & 45,77 \\
\hline G26 & 3,5 & 4,25 & 7,5 & 14 & 29,25 & 41,19 \\
\hline $\mathrm{G} 27$ & 5,25 & 2,5 & 6,75 & 13,5 & 28 & 39,44 \\
\hline G28 & 5,25 & 2,5 & 7,75 & 7 & 22,5 & 31,69 \\
\hline G29 & 5,25 & 2,5 & 7,5 & 11 & 26,25 & 36,97 \\
\hline G30 & 5 & 6 & 7,75 & 18 & 36,75 & 51,76 \\
\hline G31 & 3 & 3 & 11 & 22 & 39 & 54,92 \\
\hline G32 & 4 & 0,5 & 5 & 15,5 & 25 & 35,21 \\
\hline G33 & 6 & 3 & 10 & 12,5 & 31,5 & 44,37 \\
\hline G34 & 3,25 & 1,5 & 1 & 6 & 11,75 & 16,55 \\
\hline G35 & 4,5 & 3,5 & 5,75 & 9,5 & 23,25 & 32,75 \\
\hline G36 & 4,25 & 0,5 & 8,75 & 12,5 & 26 & 36,62 \\
\hline G37 & 4 & 3,5 & 6,25 & 12,5 & 26,25 & 36,97 \\
\hline G38 & 4 & 3 & 7,75 & 13,5 & 28,25 & 39,79 \\
\hline G39 & 4 & 3,5 & 8,25 & 7 & 22,75 & 32,04 \\
\hline G40 & 3,75 & 1 & 5,25 & 0 & 10 & 14,08 \\
\hline Jumlah & 156,5 & 103 & 290,5 & 379,5 & 929,5 & \\
\hline
\end{tabular}


Keterangan: $\quad$ SMI $1=10,5$, SMI $2=7$, SMI $3=18,5$, SMI $4=35$.

skor rata-rata $\mathrm{KP} 1=3,91$, skor rata-rata $\mathrm{KP} 2=2,58$,

skor rata-rata KP $3=7,26$, skor rata-rata $\mathrm{KP} 4=9,49$.

KP : Kategori Penguasaan.

Untuk lebih mudah dalam menentukan guru yang memenuhi dan tidak memenuhi klasifikasi penguasaan yang telah ditetapkan, skor yang diperoleh dalam Tabel 4.2 di atas dikonversi kedalam bentuk persentase terhadap skor maksimal ideal masing-masing kategori penguasaan. hasil konversi tersebut seperti terlihat dalam Tabel 4.3 berikut:

Tabel 4.2 Distribusi Skor Guru untuk Setiap Kategori Penguasaan terhadap Skor Maksimal Ideal dalam Bentuk Persentase

\begin{tabular}{|c|c|c|c|c|}
\hline \multirow{2}{*}{$\begin{array}{l}\text { KODE } \\
\text { GURU }\end{array}$} & \multicolumn{4}{|c|}{ SKOR PADA SETIAP KATEGORI PENGUASAAN } \\
\hline & KP 1 & KP 2 & KP 3 & KP 4 \\
\hline G1 & $28,57 \%$ & $0,00 \%$ & $45,95 \%$ & $18,57 \%$ \\
\hline G2 & $28,57 \%$ & $25,00 \%$ & $37,84 \%$ & $20,00 \%$ \\
\hline G3 & $47,62 \%$ & $64,29 \%$ & $50,00 \%$ & $15,71 \%$ \\
\hline G4 & $19,05 \%$ & $42,86 \%$ & $43,24 \%$ & $0,00 \%$ \\
\hline G5 & $26,19 \%$ & $64,29 \%$ & $40,54 \%$ & $20,00 \%$ \\
\hline G6 & $14,29 \%$ & $21,43 \%$ & $9,46 \%$ & $1,43 \%$ \\
\hline G7 & $47,62 \%$ & $50,00 \%$ & $52,70 \%$ & $15,71 \%$ \\
\hline G8 & $33,33 \%$ & $17,86 \%$ & $51,35 \%$ & $7,14 \%$ \\
\hline G9 & $40,48 \%$ & $7,14 \%$ & $55,41 \%$ & $14,29 \%$ \\
\hline G10 & $30,95 \%$ & $57,14 \%$ & $32,43 \%$ & $41,43 \%$ \\
\hline G11 & $30,95 \%$ & $42,86 \%$ & $39,18 \%$ & $34,29 \%$ \\
\hline G12 & $16,67 \%$ & $17,86 \%$ & $14,86 \%$ & $14,29 \%$ \\
\hline G13 & $28,57 \%$ & $21,43 \%$ & $10,81 \%$ & $12,86 \%$ \\
\hline G14 & $28,57 \%$ & $0,00 \%$ & $27,03 \%$ & $28,57 \%$ \\
\hline G15 & $47,62 \%$ & $42,86 \%$ & $45,95 \%$ & $21,43 \%$ \\
\hline G16 & $54,76 \%$ & $50,00 \%$ & $60,81 \%$ & $20,00 \%$ \\
\hline G17 & $50,00 \%$ & $50,00 \%$ & $58,11 \%$ & $22,86 \%$ \\
\hline G18 & $50,00 \%$ & $21,43 \%$ & $47,29 \%$ & $34,29 \%$ \\
\hline G19 & $38,09 \%$ & $42,86 \%$ & $52,70 \%$ & $28,57 \%$ \\
\hline G20 & $40,48 \%$ & $42,86 \%$ & $25,68 \%$ & $30,00 \%$ \\
\hline G21 & $35,71 \%$ & $35,71 \%$ & $37,84 \%$ & $50,00 \%$ \\
\hline G22 & $38,09 \%$ & $50,00 \%$ & $48,65 \%$ & $8,57 \%$ \\
\hline G23 & $33,33 \%$ & $50,00 \%$ & $37,84 \%$ & $44,29 \%$ \\
\hline G24 & $23,81 \%$ & $21,43 \%$ & $13,51 \%$ & $35,71 \%$ \\
\hline G25 & $38,09 \%$ & $50,00 \%$ & $51,35 \%$ & $44,29 \%$ \\
\hline G26 & $33,33 \%$ & $60,71 \%$ & $40,54 \%$ & $40,00 \%$ \\
\hline G27 & $50,00 \%$ & $35,71 \%$ & $36,49 \%$ & $38,57 \%$ \\
\hline G28 & $50,00 \%$ & $35,71 \%$ & $41,89 \%$ & $20,00 \%$ \\
\hline G29 & $50,00 \%$ & $35,71 \%$ & $40,54 \%$ & $31,43 \%$ \\
\hline G30 & $47,62 \%$ & $85,71 \%$ & $41,89 \%$ & $51,43 \%$ \\
\hline G31 & $28,57 \%$ & $42,86 \%$ & $59,46 \%$ & $62,86 \%$ \\
\hline G32 & $38,09 \%$ & $7,14 \%$ & $27,03 \%$ & $44,29 \%$ \\
\hline G33 & $57,14 \%$ & $42,86 \%$ & 54,05 & $35,71 \%$ \\
\hline G34 & $30,95 \%$ & $21,43 \%$ & $4,41 \%$ & $17,14 \%$ \\
\hline G35 & $42,86 \%$ & $50,00 \%$ & $31,08 \%$ & $27,14 \%$ \\
\hline G36 & $40,48 \%$ & $7,14 \%$ & $47,29 \%$ & $35,71 \%$ \\
\hline G37 & $38,09 \%$ & $50,00 \%$ & $33,78 \%$ & $35,71 \%$ \\
\hline G38 & $38,09 \%$ & $42,86 \%$ & $41,59 \%$ & $38,57 \%$ \\
\hline
\end{tabular}




\begin{tabular}{|c|c|c|c|c|}
\hline G39 & $38,09 \%$ & $42,86 \%$ & $44,59 \%$ & $20,00 \%$ \\
\hline G40 & $35,71 \%$ & $14,29 \%$ & $28,38 \%$ & $0,00 \%$ \\
\hline
\end{tabular}

Berdasarkan persentase skor rata-rata untuk kategori penguasaan 1 yaitu: 37,24\%, persentase skor rata-rata untuk kategori penguasaan $2=36,86 \%$, dan persentase skor rata-rata untuk kategori penguasaan $3=39,24 \%$. Dapat dikemukakan bahwa penguasaan guru terhadap ketiga jenis kategori penguasaan tersebut relatif sama. Untuk kategori penguasaan 4 yang merupakan pendefinisian bangun-bangun datar segitiga dan segiempat, persentase skor rata-rata masih berada di bawah skor ketiga kategori lainnya yaitu $27,11 \%$.

Bila di gambarkan dalam sebuah diagram batang, maka banyak guru yang sanga menguasai, menguasai, kurang menguasai dan tidak menguasai kategori penguasaan 1 sampai dengan 4 adalah sebagai berikut:

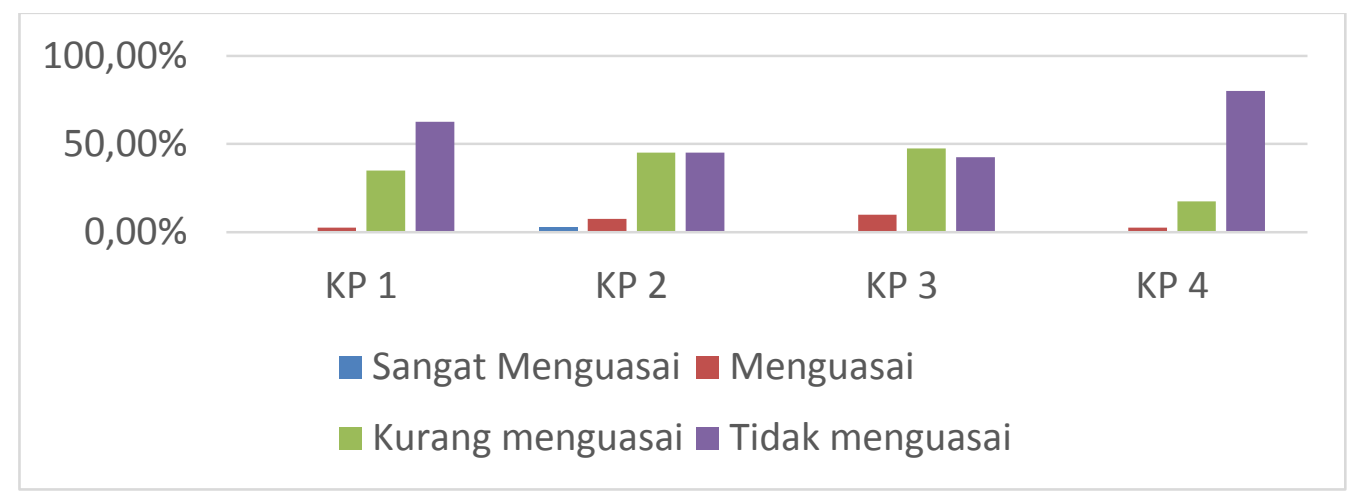

Berdasarkan hasil dari Tabel 4.2 dan diagram di atas, maka dapat dikemukakan bahwa untuk kategori penguasaan 1, kategori penguasaan 3, dan kategori penguasaan 4 tidak terdapat guru ( $0 \%$ ) yang berada pada klasifikasi penguasaan sangat menguasai, untuk kategori penguasaan 2 terdapat 2,5\% guru yang telah berada pada klasifikasi penguasaan sangat menguasai.. Untuk klasifikasi menguasai, pada kategori 1 dan 4 terdapat 2,5\% guru, kategori 2 terdapat $10 \%$ dan kategori 3 terdapat 7,5 guru.

Dengan memperhatikan persentase guru yang berada pada setiap klasifikasi penguasaan untuk setiap kategori penguasaan, maka dapat dikemukakan bahwa masih banyak guru yang tidak menguasai geometri di Madrasah Ibtidaiyah, terutama untuk kategori penguasaan 1 sebanyak 62,5\% guru dan kategori penguasaan $4(80 \%)$. Untuk kategori penguasaan 2 dan 3, walaupun persentase guru yang berada pada klasifikasi tidak menguasai berada dibawah $50 \%$ yaitu $45 \%$ untuk kategori penguasaan 1, 42,5\% untuk kategori penguasaan 2, namun persentase guru yang berada pada klasifikasi penguasaan kurang menguasai juga masih tinggi yaitu $45 \%$ untuk kategori penguasaan 2 dan 57,5\% untuk kategori penguasaan 3. 


\section{Profil Guru}

Profil yang akan disajikan yaitu: profil tentang materi ajar geometri di Madrasah Ibtidaiyah dan objek geometri madrasah ibtidaiyah yang ditunjukkan dengan skor total yang di capai oleh guru. Seperti telah dijelaskan di bab II bagian B, bahwa materi ajar geometri dikelompokkan dalam tiga kategori penguasaan. Dengan demikian untuk skor penguasaan materi ajar geometri, merupakan jumlah skor yang diperoleh pada kategori penguasaan 1, 2, dan 3.

Tabel 4.3 Distribusi Skor Tes Guru untuk Materi Ajar dan Objek Geometri

\begin{tabular}{|c|c|c|c|}
\hline \multirow[t]{2}{*}{ KODE GURU } & \multicolumn{2}{|c|}{ SKOR TOTAL } & \multirow{2}{*}{ JUMLAH } \\
\hline & MATERI AJAR GEOMETRI & OBJEK GEOMETRI & \\
\hline G1 & 11,5 & 6,5 & 18 \\
\hline G2 & 11,75 & 7 & 18,75 \\
\hline G3 & 18,75 & 5,5 & 24,25 \\
\hline G4 & 13 & 0 & 13 \\
\hline G5 & 14,75 & 7 & 21,75 \\
\hline G6 & 4,75 & 0,5 & 5,25 \\
\hline G7 & 18,25 & 5,5 & 23,75 \\
\hline G8 & 14,25 & 2,5 & 16,75 \\
\hline G9 & 15 & 5 & 20 \\
\hline G10 & 16,75 & 14,5 & 28,25 \\
\hline G11 & 14,5 & 12 & 26,5 \\
\hline G12 & 5,75 & 5 & 10,75 \\
\hline G13 & 6,5 & 4,5 & 11 \\
\hline G14 & 8 & 10 & 18 \\
\hline G15 & 16,5 & 7,5 & 24 \\
\hline G16 & 20,5 & 7 & 27,5 \\
\hline G17 & 19,5 & 8 & 27,5 \\
\hline G18 & 15,5 & 12 & 27,5 \\
\hline G19 & 16,75 & 10 & 26,75 \\
\hline G20 & 12 & 10,5 & 22,5 \\
\hline G21 & 13,25 & 17,5 & 30,75 \\
\hline G22 & 16,5 & 3 & 19,5 \\
\hline G23 & 14 & 15,5 & 29,5 \\
\hline G24 & 7,5 & 12,5 & 19 \\
\hline G25 & 17 & 15,5 & 32,5 \\
\hline G26 & 15,25 & 14 & 29,25 \\
\hline G27 & 14,5 & 13,5 & 28 \\
\hline G28 & 15,5 & 7 & 22,5 \\
\hline G29 & 15,25 & 11 & 26,25 \\
\hline G30 & 18,75 & 18 & 36,75 \\
\hline G31 & 17 & 22 & 39 \\
\hline G32 & 9,5 & 15,5 & 25 \\
\hline G33 & 19 & 12,5 & 31,5 \\
\hline G34 & 5,75 & 6 & 11,75 \\
\hline G35 & 13,75 & 9,5 & 23,25 \\
\hline G36 & 13,5 & 12,5 & 26 \\
\hline G37 & 13,75 & 12,5 & 26,25 \\
\hline G38 & 14,75 & 13,5 & 28,25 \\
\hline G39 & 15,75 & 7 & 22,75 \\
\hline G40 & 10 & 0 & 10 \\
\hline
\end{tabular}




\section{Jumlah}

5560

379,5

929,5

Keterangan: $\quad$ SMI materi ajar $=36$, SMI objek geometri $=35$.

skor rata-rata materi ajar $=13,75$, skor rata-rata objek geometri $=9,49$

Bila skor total yang diperoleh guru pada Tabel 4.3 di atas dibandingkan dengan skor maksimal yang dapat dicapai untuk materi ajar geometri di madrasah ibtidaiyah sebesar 36 dan skor maksimal yang dapat dicapai untuk objek geometri di madrasah ibtidaiyah yaitu 35 , serta dikonversikan dalam bentuk persen, diperoleh tabel skor penguasaan guru sebagai berikut:

Tabel 4.4 Distribusi Skor Guru pada Materi Ajar Geometri dan Objek Geometri dalam Bentuk Persentase

\begin{tabular}{|c|c|c|}
\hline \multirow{2}{*}{ KODE GURU } & \multicolumn{2}{|c|}{ SKOR TOTAL } \\
\hline & MATERI AJAR GEOMETRI & OBJEK GEOMETRI \\
\hline G1 & $31,95 \%$ & $18,57 \%$ \\
\hline G2 & $32,64 \%$ & $20,00 \%$ \\
\hline G3 & $52,08 \%$ & $15,71 \%$ \\
\hline G4 & $36,11 \%$ & $0,00 \%$ \\
\hline G5 & $40,97 \%$ & $20,00 \%$ \\
\hline G6 & $13,19 \%$ & $1,43 \%$ \\
\hline G7 & $50,69 \%$ & $15,71 \%$ \\
\hline G8 & $39,58 \%$ & $7,14 \%$ \\
\hline G9 & $41,67 \%$ & $14,29 \%$ \\
\hline G10 & $46,53 \%$ & $41,43 \%$ \\
\hline G11 & $40,28 \%$ & $34,29 \%$ \\
\hline G12 & $15,97 \%$ & $14,29 \%$ \\
\hline G13 & $18,06 \%$ & $12,86 \%$ \\
\hline G14 & $22,22 \%$ & $28,57 \%$ \\
\hline G15 & $45,83 \%$ & $21,43 \%$ \\
\hline G16 & $56,94 \%$ & $20,00 \%$ \\
\hline G17 & $54,17 \%$ & $22,86 \%$ \\
\hline G18 & $43,06 \%$ & $34,29 \%$ \\
\hline G19 & $46,53 \%$ & $28,57 \%$ \\
\hline G20 & $33,33 \%$ & $30,00 \%$ \\
\hline G21 & $36,81 \%$ & $50,00 \%$ \\
\hline $\mathrm{G} 22$ & $45,83 \%$ & $8,57 \%$ \\
\hline G23 & $38,89 \%$ & $44,29 \%$ \\
\hline G24 & $20,83 \%$ & $35,71 \%$ \\
\hline $\mathrm{G} 25$ & $47,22 \%$ & $44,29 \%$ \\
\hline G26 & $42,36 \%$ & $40,00 \%$ \\
\hline G27 & $40,28 \%$ & $38,57 \%$ \\
\hline G28 & $43,06 \%$ & $20,00 \%$ \\
\hline G29 & $42,36 \%$ & $31,43 \%$ \\
\hline G30 & $52,08 \%$ & $51,43 \%$ \\
\hline G31 & $47,22 \%$ & $62,86 \%$ \\
\hline G32 & $26,39 \%$ & $44,29 \%$ \\
\hline G33 & $52,78 \%$ & $35,71 \%$ \\
\hline G34 & $15,97 \%$ & $17,14 \%$ \\
\hline G35 & $38,19 \%$ & $27,14 \%$ \\
\hline G36 & $37,50 \%$ & $35,71 \%$ \\
\hline
\end{tabular}




\begin{tabular}{|c|c|c|}
\hline G37 & $38,19 \%$ & $35,71 \%$ \\
\hline G38 & $40,97 \%$ & $38,57 \%$ \\
\hline G39 & $43,75 \%$ & $20,00 \%$ \\
\hline G40 & $27,78 \%$ & $0,00 \%$ \\
\hline
\end{tabular}

Keterangan: SMI untuk materi ajar $=100$, SMI untuk objek geometri $=100$.

skor rata-rata untuk materi ajar $=38,19 \%$, skor rata-rata untuk objek geometri $=27,11 \%$, KP : Kategori Penguasaan

Berdasarkan analisis data di atas, maka untuk materi geometri di MI dapat disebutkan 25\% guru sangat menyukai, tidak ada guru yang berada pada kategori menguasai, 52,5\% guru kurang menguasai, dan $45 \%$ guru berada pada kategori tidak menguasai. Untuk objek geometri di MI, tidak ada guru yang berada pada kategori sangat menguasai maupun menguasai, $20 \%$ guru berada pada kategori kurang menguasai, dan $80 \%$ guru berada pada kategori tidak menguasai.

\section{Jenis Kesalahan dan Penyebab}

Berdasarkan data hasil tes yang telah dilakukan terhadap 40 orang guru, maka dari 40 orang guru yang diperiksa lembar jawabannya, dipilih 3 orang guru untuk dijadikan subjek wawancara. Kriteria pemilihan guru tersebut seperti yang telah dijelaskan. Guru yang terpilih sebagai subjek adalah guru dengan kode G13, G14, G17.

Agar lebih mudah berkomunikasi dalam melakukan wawancara, peniliti lebih banyak menggunakan bahasa daerah (bahasa Aceh) dalam melakukan wawancara.

Berdasarkan hasil wawancara dengan guru, dapat disimpulkan jenis dan penyebab kesalahan adalah:

\section{- Jenis kesalahan}

a. Kesalahan konsep

Kesalahan konsep yang ditemukan meliputi:

1. Konsep pencerminan;

2. Konsep sumbu simetri;

3. Konsep segiempat, trapesium, layang-layang, jajargenjang, belahketupat, persegipanjang, dan persegi;

4. Konsep sisi bangun datar;

5. Konsep sisi segitiga yang dapat dijadikan alas;

6. Mendefinisikan bangun datar segitiga dan segiempat;

7. Konsep prisma dan limas;

8. Konsep sisi bangun ruang yang dapat dijadikan alas;

9. Konsep rusuk bangun ruang;

10. Konsep sisi bangun ruang;

11. Konsep titik sudut bangun ruang.

b. Kesalahan prinsip 
Kesalahan prinsip yang ditemukan maliputi:

1. Prinsip pencerminan;

2. Prinsip keliling bangun datar;

3. Prinsip luas segitiga, luas jajargenjang, luas trapesium, dan luas belahketupat;

4. Prinsip volume tabung dan volume kerucut;

c. Kesalahan operasi

Kesalahan operasi yang ditemukan adalah kesalahan dalam operasi pencerminan.

- Penyebab kesalahan

Penyebab guru mengalami kesalahan yang ditemukan antara lain:

a. Tidak memahami konsep sumbu simetri;

b. Tidak menguasai aturan dan prinsip pencerminan;

c. Tidak memahami kedudukan cermin garis;

d. Tidak menguasai konsep segiempat, layang-layang, trapesium, belahketupat;

e. Tidak dapat mengungkapakan dengan kata-kata apa yang ada dalam pemikirannya tentang sebuah konsep;

f. Belum memahami cara mendefinisikan sebuah konsep;

g. Belum menguasai konsep sisi bangun datar;

h. Belum memahami sifat setiap sisi segitiga dapat dijadikan alas;

i. Belum dapat menentukan hubungan sisi alas dan tinggi bangun ruang;

j. Belum menguasai konsep prisma, limas, tabung, dan balok;

k. Belum memahami konsep sisi, rusuk, dan titik sudut bangun runag;

1. Tidak menguasai sifat layang-layang, jajargenjang, belahketupat, dan trapesium;

$\mathrm{m}$. Belum menguasai prinsip menghitung luas jajargenjang, trapesium, dan luas lingkaran;

n. Belum menguasai prinsip untuk menghitung volume kerucut dan tabung;

o. Salah memahami soal atau kealpaan.

\section{KESIMPULAN}

\section{Profil penguasaan Guru}

- Untuk skor kategori penguasaan materi ajar geometri di Madrasah Ibtidayah yang memuat materi bangun datar, pencerminan, bangun ruang, skor terendah 4,75 (13,19\%), skor tertinggi yaitu 20,5 (56,94\%), dan skor rata-rata $13,75(38,19 \%)$. Distribusi klasifikasi penguasaan guru yaitu: 2,5\% guru sangat menguasai, 52,5\% guru kurang menguasai, dan $45 \%$ guru yang tidak menguasai.

- Untuk kategori penguasaan objek geometri di madrasah ibtidaiyah yang memuat materi mendefinisikan bangun-bangun segitiga dan bangun-bangun segiempat. Pada kategori ini skor terendah $0(0 \%)$, skor tertinggi $22(62,86 \%)$ dengan skor rata-rata $9,49(27,11 \%)$ dengan 
distribusi klasifikasi penguasaan guru yaitu: $20 \%$ guru kurang menguasai dan $80 \%$ guru tidak menguasai.

- Secara umum penguasaan guru terhadap geometri di madrasah ibtidaiyah masih sangat rendah. Hal ini terlihat dari persentase skor rata-rata terhadap skor maksimal ideal yang dapat dicapai oleh guru hanya 13,75 (38,19\%) untuk materi ajar geometri dan 9,49 $(27,11 \%)$ untuk objek geometri di madrasah ibtidaiyah serta masih besarnya persentase guru yang berada pada klasifikasi kurang menguasai dan tidak menguasai.

\section{Jenis dan Penyebab Kesalahan.}

Dari hasil analisis jawaban guru dan wawancara, diperoleh jenis dan penyebab kesalahan yaitu: Jenis kesalahan konsep, prinsip, dan kesalahan operasi. Penyebab guru mengalami kesalahan yang ditemukan antara lain: tidak memahami konsep sumbu simetri, segiempat, tidak memahami prinsip pencerminan; Tidak menguasai sifat segiempat; Tidak terbiasa mengungkapkan definisi dari sebuah konsep; Belum memahami cara mendefinisikan sebuah konsep; Belum menguasai konsep bangun ruang, Belum memahami konsep sisi, rusuk, dan titik sudut bangun ruang; Belum menguasai prinsip menghitung luas bangun datar; Salah memahami soal atau kealpaan.

Berdasarkan kesimpulan di atas, maka dapat dikemukakan beberapa rekomendasi yaitu:

- Kepada guru matematika MI, agar berupaya semaksimal mungkin untuk terus meningkatkan penguasaannya terhadap geometri di madrasah ibtidaiyah.

- Dalam pelaksanaan pembelajaran geometri, sebaiknya para widyaiswara/dosen/tutor selalu menggunakan alat peraga secara lengkap. Hal ini selain untuk mempercepat pemahaman guru, juga berfungsi untuk mengajarkan guru bagaimana cara menyajikan sebuah konsep dengan menggunakan alat peraga kepada anak didik.

- Dalam mengajarkan sebuah konsep, misalnya konsep jajargenjang, para widyaiswara/dosen/tutor hendaknya mengarahkan guru untuk membuat definisi dari konsep yang sedang dipelajari dengan menggunakan kata-kata sendiri. Hal ini dapat dilakukan setelah dibahas sifat-sifat dari bangun yang sedang dipelajari (jajargenjang).

- Sebaiknya widyaiswara/dosen/tutor menjelaskan kepada guru bahwa antara bangun geometri yang satu dengan yang lain dapat berhubungan jika terdapat kesamaan sifat yang dimiliki. Hal ini akan mempermudah guru dalam menulis definisi konsep yang sedang dipelajari dengan menggunakan konsep sebelumnya. Disamping itu juga dapat menolong guru untuk membuat peta konsep yang akan sangat membantu pemahaman guru.

- Dalam mengajarkan sebuah prinsip, terutama prinsip yang berupa rumus (menghitung luas, keliling, dan volume) hendaknya penekanannya bukan pada bunyi dari prinsip atau rumus tersebut akan tetapi hendaknya widyaiswara/dosen/tutor lebih menekankan kepada, darimana rumus tersebut diperoleh. Hal ini dimaksudkan agar guru tidak hanya menghafal bunyi prinsip 
tersebut tetapi dapat menjelaskan dari mana prinsip tersebut diperoleh, ini juga merupakan bekal yang sangat diperlukan ketika menjadi guru.

- Penelitian ini masih merupakan langkah awal yang dapat dijadikan landasan dalam pengembangan pembelajaran. Untuk itu hasil penelitian ini diharapkan dapat dijadikan masukan pada penelitian pengembangan model pelatihan bagi guru maupun penelitian tindakan atau ekperimen yang sejenis.

\section{REFERENCES}

Clements, D. H., dan Battista, M. T. 1992. Geometry and Spatial Reasoning. dalam Grouws, D. A. (Ed.). Hand Book of Research on Mathematics Teaching and Learning. New York, Macmillan Publishing Company.

Kementerian Pendidikan Nasional. 2016. Permendiknas No 24 Tahun 2016. Depdiknas, Jakarta.

Hudoyo, Herman. 1988. Mengajar Belajar Matematika, Dikti, Jakarta.

Kennedy, I. M., dan Tipps, S. 1994. Guiding Children's Learning of Mathematics. Seventh Edition, Belmont, California: Wadsworth Publishing Company.

Miles, M.B dan Huberman A. Michel. 1992. Analisis Data Kualitatif, Terjemahan Tjejep Rohedi. UI Press, Jakarta.

Skemp, Richard R. 1982. The Psychology of Learning Mathematics, London University Press.

Soedjadi. 1992. Orientasi Kepada Kemampuan Yang Transferalde, Media Pendidikan Nasional, No. 2, Th. 1992. IKIP Surabaya.

Soedjadi. 2000. Kiat Pendidikan Matematika di Indonesia (Konstantasi keadaan masa kini menuju keadaan masa depan). Dikti, Jakarta. 